\title{
ХАРАКТЕРИСТИКА ІНСТРУМЕНТАЛЬНОГО КОМПОНЕНТУ КОНЦЕПЦIї РОЗВИТКУ КРИМІНОЛОГІЧНОГО ЗАКОНОДАВСТВА УКРАЇНИ
}

\author{
ШАБЕЛЬНІКОВ Сергій Кузьмич - аспірант Харківського національного \\ університету внутрішніх справ
}

УДК 343.9

DOI 10.32782/LAW.UA.2021.2.17

Статья посвящена исследованию проектно-программнъх составляюших предлагаемой автором концепиии развития криминологического законодательства. Акцентировано внимание на необходимости нормализации правового обеспечения государственного стратегирования, программирования и планирования в сфере противодействия преступности, правового обеспечения чеелостности противодействия преступности, развитии системы специбицированного правового регулирования предупредительной деятельности по направлениям и сберам воспроизводства преступности и пр. Обосновъвается необходимость синхронизации механизмов действия национального и международного уголовного права, правового обеспечения переходного правосудия в Украине.

Ключевъие слова: криминологическое законодательство, развитие, концепция, инструментальньий компонент, преступность, противодействие.

Постановка проблеми

3лочинність - одна 3 найбільш гострих проблем сучасності, що кидає виклик українській державності, стійкості і життєздатності суспільного договору, конвенційній, солідарній основі українства як політикоетичної, політико-правової, поліетнічної ментально-екзистенціальної колективної єдності. Ступінь i, головне, характер кримінально-криміногенних загроз на зламі тисячоліття маніфестують першочерговість уваги саме до проблем убезпечення суспільства і держави від впливу криміналітету, від тотальної криміналізації соціального устрою. Вирішення цих проблем значною мірою залежить того, яким чином правова система здатна буде інтенсифікувати власний кримінологічний сегмент, специфікувати, заточити й активізувати його на задоволення вказаних запитів. Тож розвиток кримінологічного законодавства є надактуальним завданням. При тому він не може відбуватися хаотично, має бути підпорядкований визначеній концепції.

Проблеми розвитку кримінологічного законодавства України неодноразово ставали предметом наукової уваги О. М. Бандурки, М. О. Барановського, В. С. Батиргареєвої, Я. І. Гілінського, В. В. Голіни, Д. Ю. Гончарова, А. Г. Горшенкова, О. М. Джужи, А. П. Закалюка, В. О. Зікєева, А. В. Калініної, О. М. Костенка, О. М. Литвинова, I. І. Митрофанова, Ю. В. Орлова, В. М. Поповича, О. О. Титаренка, Д. А. Шестакова та інших. Разом з тим питання концепції розвитку вітчизняного кримінологічного законодавства й досі залишаються в переліку тих, що не до кінця розроблені. Зокрема, вільною для наукового пошуку є предметна зона, що окреслює інструментальний компонент вказаної концепції.

Мета статті полягає у визначенні, описі та поясненні інструментального (про- 
грамно-проєктного) компоненту концепції розвитку кримінологічного законодавства України.

\section{Виклад основного матеріалу}

Зауважимо, що концепція розвитку кримінологічного законодавства не є концепцією чи стратегією (управлінською формою концепції) протидії злочинності у власному значенні цих категорій. Водночас було $б$ помилковим вважати, що розвиток законодавства у сфері протидії злочинності не пов'язаний зі стратегічним кримінологічним мисленням. Останне є змістовним осердям, забезпечує установки та загальну орієнтацію розвитку кримінологічного законодавства. Однак наукове обгрунтування та спрямування розвитку такого законодавства - справа ширша за окрему концепцію чи стратегію протидії злочинності.

Питання концептуального розвитку кримінологічного законодавства багатомірне: воно наскільки ж про розвиток системи управління протидією злочинності, наскільки ж і про розвиток політичної $і$ правової системи, наскільки розвиток кримінологічної і в цілому правничої науки та освіти. Саме тому концепція розвитку кримінологічного законодавства України у вбачається нами як комплекс концептуального, стратегічно-цільового, програмно-проєктного компонентів, що виходить 3 установок на все людство, людину, консолідацію українського суспільства, на множинність, нерепресивність, ліберально-гуманістичну домінанту та орієнтацій на зниження соціального неадеквату, на кримінологічну правотворчість у просторах соціальної сингулярності, фронтирності, зниження віктимності, конвергенцію кримінологічної, безпекової, гуманітарної та правової політик.

Інструментальний (програмно-проєктний) компонент концепції розвитку кримінологічного законодавства України представляє собою систему взаємопов'язаних цілей та задач тактичного порядку, спрямованих на розв'язання вузлових проблем протидії злочинності в Україні засобами кримінологічної законотворчості як інструментами реалізації програм і проєктів ан- тикримінальної діяльності. У цьому компоненті можливо виділити такі основні складові:

1) урегулювання загальних питань законотворчой діяльності, а саме:

- прийняття Закону України «Про нормативно-правові акти», який би на кшталт Закону Республіки Білорусь «Про нормативні правові акти» [1] встановив загальний порядок підготовки, оформлення, проведення експертизи (у тому числі й кримінологічної), прийняття (видання), опублікування, дії, тлумачення та систематизації вказаних актів, поняття законодавства як такого тощо. Такий закон є необхідним задля упорядкування правотворчої роботи не тільки на парламентському рівні, а й на президентському, урядовому рівнях, рівні центральних, місцевих органів державної виконавчої влади, органів місцевого самоврядування. При чому обов'язковим положенням цього закону має стати унормування кримінологічної та іншої фахової експертної оцінки (у тому числі й громадської) проєктів нормативно-правових актів на всіх без винятку рівнях;

- усунення криміногенних прогалин у Законі України «Про Регламент Верховної Ради України». Йдеться про неурегульованість процедури верифікації текстів проєктів нормативно-правових актів, що виносяться на голосування, їх остаточних (проголосованих) редакцій (що зумовлює можливість маніпуляцій, підміни остаточної редакції проголосованих текстів проєктів законів);

- унормування лобістської діяльності в Україні, детінізація політико-економічних факторів правотворчості, зниження їх криміногенності шляхом прийняття відповідного закону, встановлення чіткого порядку й процедур парламентського артикулювання інтересів груп впливу, бізнесу, громадськості;

2) унормування правового забезпечення державного стратегування, програмування та планування у сфері протидії злочинності. Наразі стан правового забезпечення цієї діяльності є вкрай незадовільним. Крім того, що відсутні загальноправові засади кримінологічного стратегування, програмування 


\section{Кримінальне право, кримінальний процес та криміналістика}

i планування, вельми фрагментованими, відірваними одна від одної (а часто й від кримінологічної науки) 6 і самі небагаточисельні програми протидії злочинності в Україні.

Правим, на нашу думку, у цьому аспекті є О. О. Титаренко, який вказує, що тривалий час система стратегічного планування в Україні перебуває на стадії розгортання [2, с. 111] та $є$ незавершеною. Базовими нормативно-правовими актами у сфері стратегічного планування є закони України «Про державне прогнозування та розроблення програм економічного і соціального розвитку України», «Про державні цільові програми». Протягом останніх років триває процес удосконалення системи стратегічного планування. Про це свідчить Концепція вдосконалення системи прогнозних і програмних документів 3 питань соціально-економічного розвитку України (2006 рік) та проєкти законів «Про державне стратегічне планування» (2011 рік), «Про нормативно-правові акти» (2010 рік) [2, с. 110-111].

На сьогодні в Україні так і не прийнято базового нормативно-правового акту у сфеpi державного стратегічного планування. Неприйнятим лишається проєкт Закону «Про державне стратегічне планування»№ 9407 від 03.11.2011 р. Водночас цей законопроєкт потребує доопрацювання та не позбавлений недоліків: по-перше, у тексті не передбачено концепції та доктрини, а також й національні проекти, що їх має сучасна українська практика державного управління. Відсутність останнього виду свідчить про інерцію розробників законопроєкту, адже національні проєкти по суті є аналогічними за рівнем програмам, але мають особливий фокус реалізації, процес управління та механізм ухвалення. Відсутність перших двох видів документів свідчить про виключення 3 процесу унормування так званих концептуально-доктринальних актів, що характеризуються вищим рівнем абстракції, ширшим колом питань і $є$ первинними щодо стратегій. Винести їх поза межі процесу стратегічного планування, що є предметом відповідного законопроєкту, недоцільно, оскільки в такий спосіб буде порушено створення цілісної ієрархічної системи керівних документів державної політики. По-друге, небезпідставно наголошує О. О. Титаренко, законопроєкт № 9407 тими строками, що їх визначено для довгострокового (понад 5 років), середньострокового (від 3 до 5 років) та короткострокового (1 рік) періодів, все ще не відповідає «класичним» підходам до визначення строків стратегічного планування. Як у теорії, так і на практиці періодичність стратегічного планування визначається так: довгострокова перспектива - 10-20 років, середньострокова - 4 (5)-10 років, короткострокова - 1-3 (4) роки [2, с. 111$]$.

Поруч з цим, зауважує вчений, сучасна проблема відсутності законодавчого закріплення стратегічних документів державної політики створює певний дисбаланс у формуванні стратегічних документів реалізації державної політики в інших сферах, у тому числі в безпековій та протидії злочинності. Але що стосується удосконалення системи стратегічного планування в останніх та унормування стратегічних та програмних документів, то в цьому напрямку останнім часом спостерігаються позитивні зрушення. Вони здебільшого пов'язані з прийняттям нового Закону України «Про національну безпеку України» 21.06.2018 р. [2, c. 111-112]. 3 цими судженнями не можна не погодитись. Вони є аргументованими та заслуговують на підтримку, подальший розвиток та втілення у кримінологічному законодавстві;

3) правове забезпечення иілісності протидї злочинності, ефективної взаємодії державного, муніципального та недержавного (приватного, громадського) секторів запобіжної діяльності:

- удосконалення правових засад державно-приватного партнерства у сфері протидї злочинності. Ю. В. Орлов пропонує розглядати таке партнерство крізь призму концепції політичного антикриміналізму [3,с. 483-508, 653-655]. 3 цим, звісна річ, можна погодитись, розвинувши ідею до більш широких меж, що виходять за вказану вченим концепцію. Доцільним, на нашу думку, є, по-перше, функціональне та суб'єктне 
розширення згаданого інституту до публічно-приватного, включивши, таким чином, до нього й муніципалітет, який обгрунтовано в кримінологічній науці вважається потенційно вельми ефективним суб'єктом протидії злочинності на місцевому рівні (ця думка розлого репрезентована та грунтовно доведена в працях О. П. Шайтуро, О. С. Шеремета й деяких інших дослідників). По-друге, запровадження інструменту кримінологічних угод між публічною адміністрацією (органами державної влади, місцевого самоврядування) та приватними суб'єктами з метою використання їх можливостей (у тому числі інвестиційних) у кримінологічних цілях в обмін на преференції у сфері господарювання (оподаткування, квотування, оренди тощо);

удосконалення правових засад залучення громадськості до протидї злочинності, взаємодії громадськості 3 правоохоронними органами. Цей напрям наукового забезпечення криімнологічної практики широко представлений працями В. В. Голіни, М. Г. Колодяжного, що звільняє нас від необхідності у додаткових аргументах щодо необхідності удосконалення правового регулювання громадського запобігання злочинам, наявності для цього належної теоретичної бази;

4) розбудова системи специфікованого правового регулювання запобіжної діяльності за напрямами та сферами відтворення злочинності. Наразі в Україні правове забезпечення протидії злочинності $є$ надто узагальненою, універсальною, не підлашвтованою під запити у нейтралізації чи мінімізації впливу детермінант окремих видів злочинності (мова тут йдеться саме про запобігання). Водночас прогресивний зарубіжний досвід свідчить про ефективність зворотного підходу, підходу кримінологічної специфікації.

Наприклад, доктрина Закону про превентивні заходи проти насильницьких груп 1992 р. в Японії націлена на створення не просто державної, а загальнонаціональної боротьби 3 нею, що включає мережу активно діючих громадських формувань, інтеграції соціальних і правових засобів боротьби з цим злом [4, с. 133]. Це знахо- дить своє вираження, зокрема, в залученні родичів правопорушників до нагляду за ними. Крім того, слід згадати різного роду громадські формування, які беруть участь у запобіганні злочинам та охороні громадського порядку. У їх числі, наприклад, асоціація запобігання крадіжкам у багатоквартирних будинках; асоціація, що займається запобіганням розбійним нападам на фінансові установи; асоціація «наставників неповнолітніх», націлена на виявлення неблагополучних підлітків і проведення з ними виховної роботи. У межах цієї діяльності постійно ведеться робота 3 надання допомоги членам «боріокудан», які бажають порвати 3 кримінальною організацією; на підприємствах, особливо привабливих для гангстерів, префектурні центри по забезпеченню заходів боротьби 3 насильством у співпраці з поліцією проводять семінари для персоналу [5, с. 214-215]. Таким чином, специфікація законодавчого забезпечення запобігання злочинам пронизує всі рівні правового регулювання: від загальнодержавного до муніципального (особливо муніципального) й об'єктового (на окремих підприємствах, установах). Однак зрозуміло, що державі (а надто в українських соціокультурних реаліях) у цій справі має належати роль модератора, ініціатора;

5) удосконалення загальних правових засад запобіжної діяльності органами Національної поліцї та іншими правоохоронними органами. Йдеться, зокрема, про відновлення так званої слідчої профілактики, повернення до КПК України норм про обов'язок слідчого, дізнавача виявляти причини та умови вчинення кримінального правопорушення на індивідуальному рівні, форми та методи реагування на виявлені фактори (див. додаток).

Також існує гостра потреба в науковій кримінологічній ревізії та приведенні у відповідність до реальних запитів у запобіганні (а не лише розкритті і розслідуванні) злочинам положень Інструкції з організації взаємодії органів досудового розслідування 3 іншими органами та підрозділами Національної поліції України в запобіганні кримінальним правопорушенням, їх виявленні та розслідуванні від 07.07.2017 р. № 575 [6]. 


\section{Кримінальне право, кримінальний процес та криміналістика}

Навіть побіжний аналіз цього нормативноправового акту дозволяє пересвідчитись, що він жодним чином не зорієнтований на урегулювання взаємодії за напрямом превенції, сфокусований тільки на питаннях розкриття та розслідування кримінальних правопорушень.

Прогальним наразі залишається і правове забезпечення взаємодії Національної поліції з іншими правоохоронними органами як у справі запобігання, так і розслідування, розкриття кримінальних правопорушень. Замість скасованого ще у 2014 р. спільного наказу МВС, СБУ, Державного комітету у справах охорони державного кордону України, Державного митного комітету України, Національної гвардії України, Міністерства оборони України, Міністерства юстиції України «Про взаємодію правоохоронних та інших державних органів України у боротьбі зі злочинністю» від 10.08.1994 р. № 4348/138/151/11-2-2870/172/148-408/290-442 [7] новий не прийнятий. На нашу думку, цей аспект протидії злочинності, враховуючи його міжвідомчий характер, а також динамізм структурно-функціональних змін у системі органів державної виконавчої влади, має віднайти своє правове урегулювання на рівні базового кримінологічного закону (див. додаток);

6) організаиійно-правова інституиіоналізаиія моніторингу еббективності правового регулювання у сбері протидї злочинності (його теоретичні основи розроблені у працях Е. М. Блажівського, Ю. Д. Блувштейна, Г. М. Горшенкова, О. М. Аитвинова, Д. О. Миронюка, Ю. В. Орлова й деяких інших учених) через створення Управління моніторингу правового регулювання у сфері протидії злочинності як структурного підрозділу Центру кримінологічного моніторингу, діяльність якого можливо розгорнути на базі Науково-дослідного інституту вивчення проблем злочинності імені академіка В. В. Сташиса Національної академії правових наук України;

7) конвергениія національного (внутрішньодержавного) та міжнародного кримінального nрава. Конституційно-правові засади для цього поступу вже закладено із прийняттям та набуттям чинності норми про те, що
Україна може визнати юрисдикцію Міжнародного кримінального суду на умовах, визначених Римським статутом Міжнародного кримінального суду (ч. 6 ст. 124 Конституції України [8]). Надалі - складний процес адаптації КК під умови альтернативної (розширеної) джерельності кримінального права України 3 подальшою ратифікаиією Римсъкого статуту Міжнародного кримінального суду. 3 приводу останнього важливо акцентувати на двох моментах.

По-перше, ми стоїмо на позиціях необхідності та доцільності ратифікації вказаного статуту з огляду на виклики глобалізованої злочинності, потерпання нашої держави від злочинів агресії, воєнних злочинів, злочинів проти людяності (у категоріях Римського статуту), необхідності залучення і до реакції на їх вчиненні, і до запобігання подальшому поширенню, розширенню театру радикальної політико-кримінальної активності ефективних міжнародних механізмів. Водночас, не позбавленими сенсу і 6 зауваження Ю. В. Орлова щодо: а) ризиків ратифікації Римського статуту для суспільно-політичної ситуації в Україні (а через неї - й до актуалізації загроз державності, детермінант політичної злочинності) у зв'язку з можливим притягненням до міжнародної кримінальної відповідальності в числі інших злочинів і тих, які зі зброєю в руках відстоювали державний суверенітет на Сході України, але супутньо допустили вчинення відповідних злочинів; б) необхідності визначитись зі стратегією боротьби 3 агресором, у контексті якої і підходити до вирішення проблем ратифікації Римського статуту [9, с. 20-25].

По-друге, потребують істотних змін і доповнень положення КК України про чинність закону про кримінальну відповідальність у просторі, які 6 відкривали законні можливості для застосування просторової юрисдикції Міжнародного кримінального суду щодо злочинів, вчинених на теритоpiї України. Чинна нині редакція ст. 6 КК України не дає такої можливості;

8) правове забезпечення перехідного правосуддя в Україні. Наразі офісом уповноваженого з прав людини Верховної Ради України, у взаємодії з міжнародними організаціями 
за підтримки громадських організацій (передусім - Української Гельсінської спілки з прав людини) розроблено проєкт Закону України «Про засади державної політики захисту прав людини в умовах подолання наслідків збройного конфлікту» [10]. Цей законопроєкт зорієнтований на реалізацію чотирьох основних напрямів концепції перехідного правосуддя: притягнення винних до відповідальності, відшкодування завданої шкоди, встановлення історичної правди, інституційні реформи, спрямовані на неповторення майбутнього. Вказаний проєкт закону забезпечений ще кількома супутніми, які передбачають переслідування за прояви колабораціонізму, посилення відповідальності за державну зраду, законопроєкт «Про прощення» та ін. [11].

Підтримуючи в цілому ініціативи авторів законопроєкту, варто в той же час зважати і на те, що він підготовлений з урахуванням дійсно широкого досвіду реалізації перехідного правосуддя в низці країн світу, однак такого досвіду, який може бути застосований щодо ситуації в Україні зі значними корективами. Передусім через те, що він, цей досвід, сформований в умовах, відмінних від сучасних, у яких розвиваються (існують) постмодерні суспільства. У значній мірі відмінності цих умов визначаються відмінностями у темпах соціального часу, легкістю, масовістю доступу до інформації, перенасиченістю інформаційних полів, розвиненістю технологій конструювання групових габітусів, симуляції постпам'яті, «ігор»на травматичному досвіді (Ю. В. Орлов [12, с. 11-31]). Усі ці фактори мають істотні національні (внутрішньодержавні) особливості; вони потребують врахування. Інакше ініціативи щодо реалізації перехідного правосуддя матимуть значний криміногенний потенціал. Відтак, є потреба у розробці кримінологічних засад перехідного правосуддя, кримінологічної експертизи та корегування вже розроблених законопроєктів. I це - питання національної безпеки, у зв'язку з чим воно включене нами до концепції розвитку кримінологічного законодавства.

\section{Висновки}

Підсумовуючи, зауважимо, що основний замисел концепції розвитку кримінологічного законодавства - створення мисленнєвих (наука, освіта), інституційних та юридичних підстав для його керованого конструювання, забезпечення функціонування як цілісного правового феномену 3 визначеними моніторинговими параметрами та адекватними предметно-змістовними, структурно-функціональними конфігураціями, зорієнтованими на вирішення як зовнішніх (власне кримінологічних, пов'заних 3 криміногенними викликами), так і внутрішніх (юридико-догматичних) проблем. Охарактеризований інструментальний компонент $\epsilon, 3$ одного боку, складовою тактичного порядку, реалізація якої спрямована на покрокове, але системне удосконалення кримінологічного законодавства за найбільш затребуваними напрямами, а по-друге, є відкритим, не має розглядатися як довершений. Загалом концепція розвитку кримінологічного законодавства, маючи у своїй основі стійкий фундамент установок та орієнтацій, вирізняється динамічністю й адаптивністю саме за рахунок складників інструментального компоненту. Реалізації останніх - справа політичної волі.

\section{Лiтература}

1. О нормативных правовых актах : Закон Республики Беларусь от 17.07.2018 г. № 130-3. URL : https://pravo.by/document/? guid $=3871 \& p 0=$ H 11800130 (дата звернення: 09.03.2021).

2. Титаренко О. О. Теорія та практика державного програмування протидії злочинності в Україні : дис. ... докт. юрид. наук : 12.00.08 ; Харківський національний університет внутрішніх справ. Х., 2020.589 c.

3. Орлов Ю. В. Політико-кримінологічна теорія протидії злочинності : монографія. Харків : Діса Плюс, 2016. 656 с.

4. Иванов А. М. Организованная преступность и борьба с ней в Японии. Владивосток : Изд-во ДВГУ, 2000. 282 с.

5. Морозов Н. А. Япония : преступность и уголовная политика / Под ред. и 


\section{Кримінальне право, кримінальний процес та криміналістика}

вступ. статья В. Е. Квашиса. СПб. : Юрид. Центр, 2016. 400 с.

6. Інструкція 3 організації взаємодії органів досудового розслідування 3 іншими органами та підрозділами Національної поліції України в запобіганні кримінальним правопорушенням, їх виявленні та розслідуванні : Наказ МВС України від 07.07.2017 p. № 575. URL : https://zakon. rada.gov.ua/laws/show/z0937-17\#Text (дата звернення: 06.06.2021).

7. Про взаємодію правоохоронних та інших державних органів України у боротьбі зі злочинністю : наказ Міністерства внутрішніх справ України, Служби безпеки України, Державного комітету у справах охорони державного кордону України, Державного митного комітету України, Національної гвардії України, Міністерства оборони України, Міністерства юстиції України від 10.08.1994 р.№ 4348/138/151/11-2-2870/172/148-408/290-442 (наказ втратив чинність на підставі наказу Міністерства внутрішніх справ від 20.01.2014 p. № 35/13/45/41/102/5). URL : https://zakon.rada.gov.ua/laws/show/z022594\#Text (дата звернення: 09.03.2021).

8. Конституція України : Закон України від 28.06.1996 р.№ 254к/96-BP. URL : https://zakon. rada.gov.ua/laws/show/254\%D0\%BA/96\% D0\%B2\%D1\%80\#Text (дата звернення: 02.06.2021).

9. Орлов Ю. В. Ратифікація Римського статуту Міжнародного кримінального суду та елементи політики у сфері протидії злочинності в Україні: проблеми гармонізації. Вісник Кримінологічної асоціащй Украйни. 2020. № 1 (22). С. 16-26.

10. Про засади державної політики захисту прав людини в умовах подолання наслідків збройного конфлікту : проєкт Закону України від 26.01.2018 p. URL : http:// hro.org.ua/files/docs/1524118917.pdf (дата звернення: 01.11.2020).

11. Презентація законопроекту «Про засади державної політики захисту прав людини в умовах подолання наслідків збройного конфлікту» / Українська Гельсінська спілка 3 прав людини. URL : https://helsinki.org.ua/articles/prezentatsiya- zakonoproektu-pro-zasady-derzhavnojipolityky-zahystu-prav-lyudyny-v-umovahpodolannya-naslidkiv-zbrojnoho-konfliktu/ (дата звернення: 05.06.2021).

12. Орлов Ю. В. Traumastudies у фокусі кримінологічного аналізу (український контекст). Вісник Кримінологічної асощіащиї Украӥни. 2020. № 2 (23). С. 11-31.

Serhiy K. SHABELNIKOV, graduate student (Kharkiv National University of Internal Affairs, Kharkiv, Ukraine)

\section{CHARACTERISTIC OF THE INSTRU- MENTAL COMPONENT OF UKRAINIAN CRIMINOLOGICAL LEGISLATION DE- VELOPMENT'S CONCEPT}

The article is devoted to the study of the design and program components of the concept of the development of criminological legislation proposed by the author. Attention is focused on the necessity to normalize the legal support of state strategy-dividing, programming and planning in the field of combating crime, legal support of the integrity of combating crime, the development of a system of specified legal regulation of preventive activities in areas of reproduction of crime, improvement of general legal bases of preventive activity by bodies of National police and other law enforcement bodies, organizational and legal institutionalization of monitoring of efficiency of legal regulation in the field of counteraction to crime. At that moment in Ukraine the legal framework for combating crime is too generalized, universal, not tailored to the demands of neutralizing or minimizing the impact of the determinants of certain types of crime (this is about prevention). At the same time, progressive foreign experience testifies to the effectiveness of the reverse approach, the criminological specification approach.

The need to adopt the Law of Ukraine "On Legal Acts", eliminate criminogenic gaps in the Law of Ukraine "On the Rules of Procedure of the Verkhovna Rada of Ukraine", normalize lobbying in Ukraine, de-shadow political and economic factors of lawmaking, reduce their criminogenicity by adopting the law, establishing a clear procedure and procedures for parliamentary articulation of the interests of influence groups, business, and the public. Legal support of integrity of counteraction to crime, effective interaction of the state, municipal and non- 
Шабельніков С.К. - Характеристика інструментального компоненту концепцї...

\section{АНОТАЦІЯ}

Стаття присвячена дослідженню проєктно-програмних складових пропонованої автором кониепиї розвитку кримінологічного законодавства. Акцентовано увагу на необхідності унормування правового забезпечення державного стратегування, програмування та планування у сбері протидії злочинності, правового забезпечення излісності протидій злочинності, розбудові системи специфікованого правового регулювання запобіжної діяльності за напрямами та сферами відтворення злочинності тощо. Наголошено на запиті у синхронізачй механізмів дї̈ начіонального та міжнародного кримінального права, правового забезпечення перехідного правосуддя в Україні.

Ключові слова: кримінологічне законодавство, розвиток, концепція, інструментальний компонент, злочинність, протидія.

state (private, public) sectors of preventive activity provides: a) improvement of legal bases of publicprivate partnership in the field of counteraction to crime.
It is proposed to introduce an instrument of criminological agreements between public administration (public authorities, local governments) and private entities in order to use their opportunities (including investment) for criminological purposes in exchange for preferences in the field of management (taxation, quotas, leases, etc.). Also highlighted on improving the legal framework for public involvement in combating crime, public interaction with law enforcement agencies.

The necessity of synchronizing the mechanisms of action of national and international criminal law, also legal support of transitional justice in Ukraine is substantiated. We stand on the position of the necessity and expediency of ratification of Rome Statute of the International Criminal Court in view of the challenges of globalized crime, the suffering of our state from crimes of aggression, war crimes, crimes against humanity (to the categories of the Rome Statute), the need to involve and prevent further expansion, expansion of the theater of radical political and criminal activity of effective international mechanisms.

Key words: criminological legislation, development, concept, instrumental component, crime, counteraction. 